\title{
Effects of Short-Term Alkaline Adaptation on Surface Properties of Listeria monocytogenes $10403 \mathrm{~S}$
}

\author{
Efstathios S. Giotis*, Ian S. Blair and David A. McDowell
}

Food Microbiology Research Group, University of Ulster, Northern Ireland, UK

\begin{abstract}
The changes in cell surface properties associated with alkali stress can significantly disrupt cell metabolism and structures, preventing effective interactions between bacterial cells and their environment. Listeria monocytogenes is known to display an adaptive response to alkali stress that enhances its capacity to more effectively survive subsequent severe alkali challenge. In this study, we examined the effects of adaptation to alkali conditions ( $\mathrm{pH} 9.5 / 1 \mathrm{~h}$ ) in reducing detrimental effects in hydrophobicity and cell morphology in Listeria monocytogenes $10403 \mathrm{~S}$ during severe (subsequent)

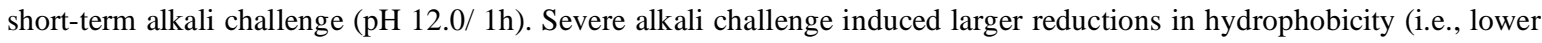
MATH values) in non adapted control cells than in mild alkali adapted cells. SEM revealed greater morphological diversity in suspensions of non alkali adapted cells than in suspensions of mild alkali adapted cells, i.e., a larger proportion of alkali adapted cells retained the normal (bacillary) morphology. Non adapted cells displayed considerable morphological heterogeneity including elongation, rupture and cellular deformation. Short-term alkaline adaptation in L. monocytogenes involves direct changes in the cell surface properties and organisation which facilitate the well recognised phenotypic abilities of this pathogen to persist and/or grow in alkaline conditions. Alkali adaptation may be significant in the persistence of this pathogen in the presence of alkali detergents in food processing environments and alkali natural habitats, and has direct clinical implications in relation to virulence and response to mammalian defence mechanisms.
\end{abstract}

Keywords: Listeria, alkali, stress, hydrophobicity, surface, morphology.

Listeria monocytogenes is an important food borne pathogen due to its ability to resist environmental stresses and initiate high mortality rate human infections [1]. In particular, its considerable capacity to resist alkali stress may explain its persistence in food processing environments where decontamination procedures are significantly dependent on the use of alkali detergents [2-5]. Similarly, alkali resistance is suggested as important in enabling this pathogen to survive and establish infection in humans where it is challenged by pancreatic secretions [6], and the alkaline phase of phagocytosis [7].

L. monocytogenes is known to display an adaptive response in which exposure to non lethal environmental stress, enables it to more effectively survive subsequent [more severe] challenges by the same or different environmental stress(es) [8-12]. Such adaptation has been noted in response to alkali stress [13-17], and has also been reported to confer cross protection against subsequent thermal stress, ethanol and alcohol stress $[4,11,18]$.

Alkali conditions can induce the solubilisation of bacterial surface proteins $[19,20]$, resulting in exposure of hydrophobic sites of adjacent lipids to the extracellular environment [21]. Alkali may also directly attack the structure of the cell membrane by saponification of membrane lipids or alteration of the membrane fatty acids ratio [22, 23]. The changes in cell surface properties and structures associated

\footnotetext{
*Address correspondence to this author at the Centre for Endemic, Emerging and Exotic Diseases (CEEED), Royal Veterinary College, London, Hawkshead Lane, AL9 7TA, UK; Tel: ++44(0)1707667038, 02890 366697; Mobile: ++44(0)7896498097; Fax: +44(0)1707667051, 02890 368811; E-mail: egiotis@ rvc.ac.uk
}

with alkali and/or other environmental induced damage can significantly disrupt cell metabolism and structure, preventing effective interactions between bacterial cells and their environment [24].

Considerable information is available about the general structure and biochemistry of the surface of L. monocytogenes, although less is known about the direct physical effects of environmental stresses and in particular alkali stress, on these structures and processes. To our knowledge this is the first study to investigate the relationship between alkaline adaptation and the associated changes in cell size and surface characteristics in order to determine possible mechanisms of resistance to short term alkali stress. A previous study [5] dealt with the long term alkali- induced change in bacterial size and morphology while this follow-up study reports the short term (i.e. $1 \mathrm{~h}$ ) alkali- induced bacterial size changes as a resistance mechanism in combination with surface properties $(\mathrm{CSH})$ alterations.

Listeria monocytogenes $10403 \mathrm{~S}$ cells (BHI, $\mathrm{pH} 7.2,30^{\circ} \mathrm{C}$, $\mathrm{OD}_{600} \approx 0.4$ ), were pelleted by centrifugation and resuspended into alkali adjusted $\mathrm{BHI}$ ( $\mathrm{pH} 9.5$ with $2 \mathrm{M} \mathrm{NaOH}, 30^{\circ} \mathrm{C}$ ) or into $\left(30^{\circ} \mathrm{C}\right) \mathrm{BHI}(\mathrm{pH} 7.2)$. After incubation $\left(30^{\circ} \mathrm{C} / 60 \mathrm{~min}\right)$, cells were recovered and placed in $\mathrm{BHI}\left(30^{\circ} \mathrm{C}\right)$ adjusted to $\mathrm{pH} 12.0(2 \mathrm{M} \mathrm{NaOH})$ for 60 mins. Control cultures were adapted to $\mathrm{pH} 7.2$, recovered by centrifugation, and resuspended in fresh BHI. Specimens were examined/photographed with a Hitachi S3200N scanning electron as previously described [5]. Cell dimensions (length, width, equatorial radius of spheroid caps) were recorded, and used to calculate cell volumes in the equation $V\left(\mu \mathrm{m}^{3}\right)=\pi / 4$ $w^{2} L+\pi / 3 W^{2} R$, which assumes cells to be cylindrical with an hemisphere at each end [25]. $W$ represented cell width of the 
central part of the cylindrical cell, $L$ represents cell length of the central part of the cell, and $R$ represents equatorial radius of spheroid caps [26]. Surface hydrophobicity was measured by a modification of the microbial adhesion to hydrocarbons (MATH) assay [27, 28]. Alkali challenged cells recovered from BHI ( $\mathrm{pH}$ 12.0), and control cells recovered from BHI $(\mathrm{pH}$ 7.2) were resuspended in $1.2 \mathrm{ml}$ of PBS (pH 7.4) to absorbance values between 0.9-1.0 $[\lambda=400 \mathrm{~nm}]$, and vortex mixed with $100 \mu 1 p$-xylene (Sigma) for 120 secs. The absorbance at $400 \mathrm{~nm}$ was estimated using a UV/Vis spectrophotometer (Shimatzu UV-1201), and the percentage adherence to $p$-xylene was calculated as $\left(\mathrm{abs}_{1}-\mathrm{abs}_{2}\right) / \mathrm{abs}_{1} \times 100$, where $a_{b} s_{1}$ is the absorbance of the initial bacterial suspension and $\mathrm{abs}_{2}$ is the absorbance of the aqueous phase. Experiments were done in triplicate.

\section{EFFECT OF PH ON CELL MORPHOLOGY}

Control (pH 7.2) cultures displayed little or no morphological heterogeneity after the growth, centrifugal recovery, and PBS washing processes. However, alkali challenged ( $\mathrm{pH}$ 12.0) (adapted and non adapted) cultures exhibited considerable morphological heterogeneity, including ruptured, deformed, wrinkled and/or elongated cells in comparisons with control cultures (Fig. 1). There was a significant difference $(P=0.005)$ between the mean cell volume of alkali challenged $(\mathrm{pH}$ 12.0) non adapted cultures, and the mean cell volumes of control ( $\mathrm{pH}$ 7.2) populations. There was no significant difference between the mean cell volume of alkali challenged ( $\mathrm{pH}$ 12.0) adapted cultures, and control ( $\mathrm{pH} 7.2)$ populations (Table $\mathbf{1}$ ).

The results obtained in this study confirmed that $\mathrm{pH} 12.0$ presented a very hostile environment to L. monocytogenes. SEM analysis revealed that alkali stress induced significant diversification of cell morphologies including cell deformation and elongation. This is in agreement with a previous SEM study of Listeria monocytogenes subjected to extreme (pH 12.0) alkali conditions [5]. Another study also reported distinct clear and dark zones in Listeria cells and a bulging cytoplasmic membrane against the cell wall [22]. The extent of the disruption observed in these studies provide some in- dication of the extent of physical disruption which underlies previous reports of severe and abrupt cessation and/or dysfunctions of cell division under high $\mathrm{pH}$ conditions, as previously discussed in the proposed bacterial suicidal response hypothesis [29]. The elongated forms of Listeria cells observed in this study have also been previously reported [5].

The scale of the above changes occurred to different extents in adapted and nonadapted populations of L. monocytogenes. Alkaline adapted cells did not significantly change their mean cell volumes during exposure to $\mathrm{pH} 12.0$ for 60 mins, but under the same conditions non adapted cells showed a significant reduction in mean cell volume. Similarly, adapted populations displayed less diversity of cell shape during severe short-term alkaline challenge.

Alkali conditions similar to the conditions examined in this study are commonly found in food industry environments and in the human gastrointestinal system. Thus, further work should be undertaken to estimate the extent of morphological changes in the global stress modification of $L$. monocytogenes.

\section{EFFECT OF PH ON CELL SURFACE HYDROPHO- BICITY}

Cell surface hydrophobicity (CSH) values for cultures adapted/or not adapted at $\mathrm{pH} 9.5$ are presented in Table $\mathbf{1}$. Cells from alkaline challenged $(\mathrm{pH} 12.0)$ cultures (adapted and not adapted) had significantly $(P<0.05)$ lower MATH scores than cells from control ( $\mathrm{pH} 7.0)$ cultures. The average MATH scores of cells from adapted cultures were significantly higher than the MATH scores of cells from non adapted cultures, suggesting less disruption of normal hydrophobicity status in adapted cells.

This study noted that short term severe alkaline stress led to significant reductions in cell surface hydrophobicity in $L$. monocytogenes. This study is the first to report the semi protective effects of short alkali adaptation in limiting the impact of severe alkali challenge on cell hydrophobicity. This suggests that the process of adaptation to mild alkali stress involves direct physical and/or chemical changes which limit

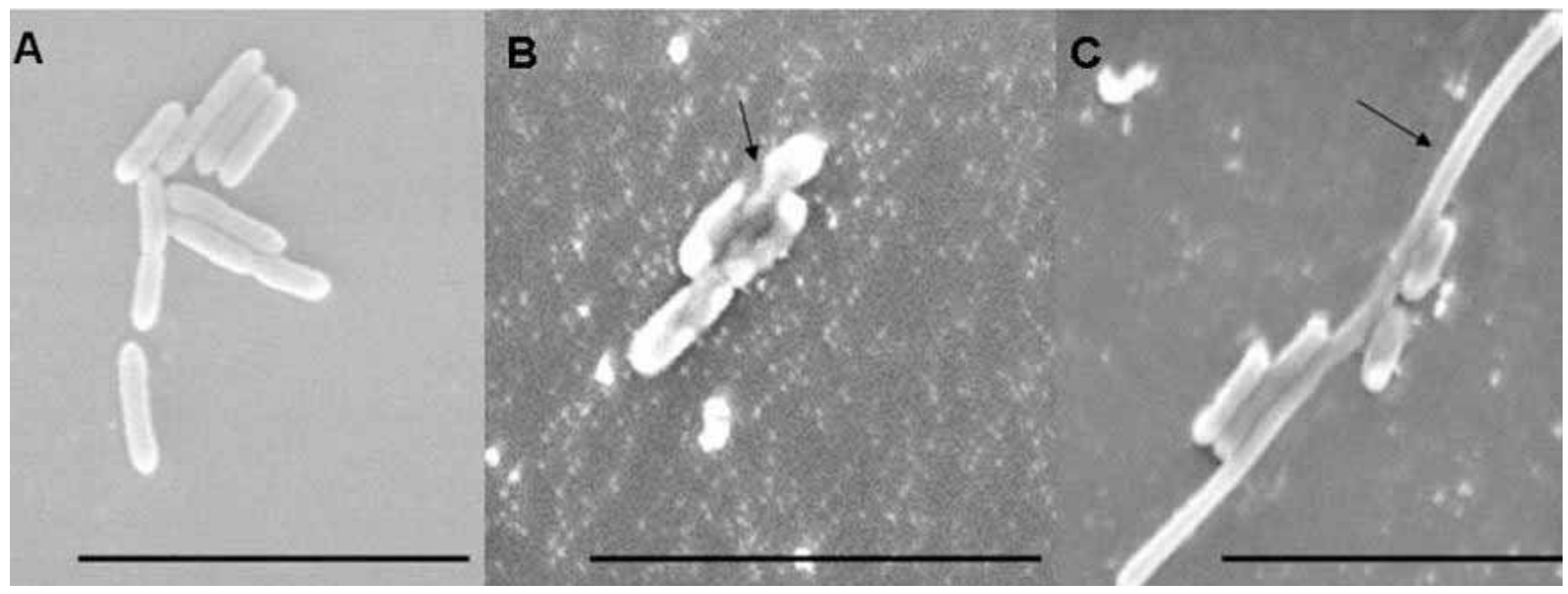

Fig. (1). Electron micrographs of non alkali adapted ( $\mathrm{pH}$ 7.2) and alkali adapted (pH 9.5) L. monocytogenes after alkali challenge (pH 12.0/1 hr) $(\mathrm{Bar}=5 \mu \mathrm{m})$. A: Control cells ( $\mathrm{pH} 7.2 / \mathrm{pH} 7.2), \mathbf{B}$ : Non alkali adapted cells (pH 7.2/ $\mathrm{pH} 12.0)$ (Arrow indicates cell rupture), C: Alkali adapted cells ( $\mathrm{pH} 9.5 / \mathrm{pH} 12.0)$ (Arrow indicates elongated cell). 
Table 1. Mean Cell Sizes and Surface Hydrophobicity Values of L. monocytogenes Populations After Alkali Challenge (pH 12.0/1 h)

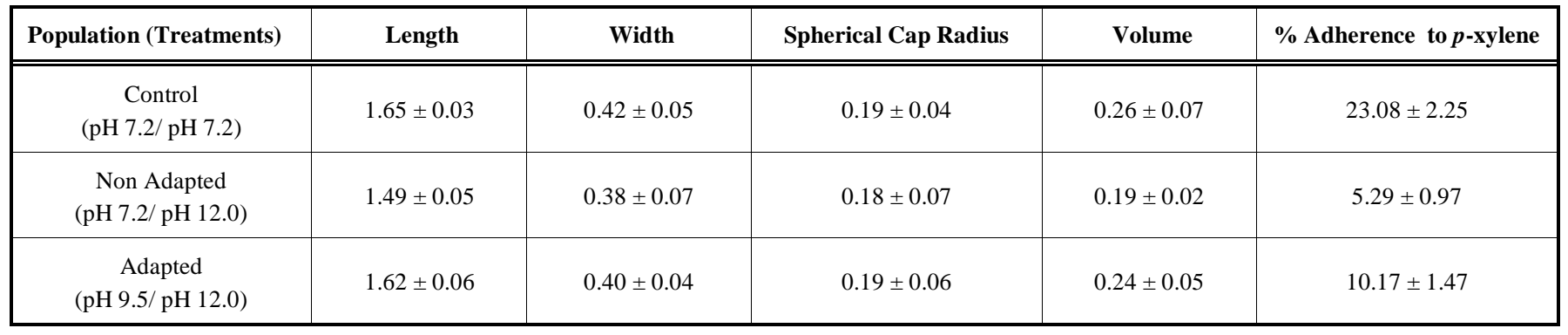

*Values represent the means \pm S.D. of three separate experiments.

the impact of subsequent severe alkali challenge on those components of the cell surface which contribute to cell surface hydrophobicity.

Higher CSH values have been correlated with enhanced adherence to host epithelial cells [30] and effective formation of biofilms [31]. Therefore, the impact of adaptation in limiting the extent by which alkali challenge may reduce $\mathrm{CSH}$ values may indicate a broader protective effect of adaptation in limiting cell surface disruption and/or maintaining a wider range of such cell surface activities. However, it is important to note that the significant surface components which contribute to $\mathrm{CSH}$ in Listeria are different from the types of surface of components which dictate $\mathrm{CSH}$ values in Gram-negative bacteria CSH values that are principally dictated by polysaccharides or (glyco-) proteinaceous material [32]. In Listeria, such materials are very limited or completely absent, and stress related changes in $\mathrm{CSH}$ in this organism involve changes in teichoic acids and/or peptidoglycans [33]. Interestingly, alterations in teichoic acids have also been reported to contribute to the alkaline tolerance of species of Bacillus [34].

Further work is needed to characterise the changes that take place on the cell surface of Listeria under alkali stress in order to better understand the impact of alkali stress, and the adaptive response of this pathogen to such stress, in attachment, persistence, and virulence.

\section{ACKNOWLEDGEMENTS}

The authors are very grateful to the Northern Ireland Biomedical Engineering Centre (NIBEC) for the use of microscopy facilities. The authors would particularly like to thank Drs Don Saville and Patrick Lemoine for their technical advice and practical assistance. Efstathios Giotis is supported by a University of Ulster Vice-Chancellor Research Scholarship.

\section{REFERENCES}

[1] Farber JM, Peterkin PI. Listeria monocytogenes, a foodborne pathogen. Microbiol Rev 1991; 55: 476-511.

[2] Taormina PJ, Beuchat LR. Survival and growth of alkali-stressed Listeria monocytogenes on beef frankfurters and thermotolerance in frankfurter exudates. J Food Prot 2002; 65: 291-8.

[3] Taormina PJ, Beuchat LR. Survival of Listeria monocytogenes in commercial food-processing equipment cleaning solutions and subsequent sensitivity to sanitizers and heat. J Appl Microbiol 2002; 92: 71-80.

[4] Taormina PJ, Beuchat LR. Survival and heat resistance of Listeria monocytogenes after exposure to alkali and chlorine. Appl Environ Microbiol 2001; 67: 2555-63.
[5] Giotis ES, Blair IS, McDowell DA. Morphological changes in Listeria monocytogenes subjected to sublethal alkaline stress. Int J Food Microbiol 2008; 120: 250-8.

[6] Giannell RA, Broitman SA, Zamcheck N. Influence of gastric acidity on bacterial and parasitic enteric infections - perspective. Ann Int Med 1973; 78: 271-6.

[7] Segal AW, Geisow M, Garcia R, Harper A, Miller R. The respiratory burst of phagocytic cells is associated with a rise in vacuolar pH. Nature 1981; 290: 406-9.

[8] Beales N. Adaptation of microorganisms to cold temperatures, weak acid preservatives, low $\mathrm{pH}$, and osmotic stress: a review. Compr Rev Food Sci Food Saf 2004; 3: 1-20.

[9] Hill C, Cotter PD, Sleator RD, Gahan CGM. Bacterial stress response in Listeria monocytogenes: jumping the hurdles imposed by minimal processing. Int Dairy J 2002; 12: 273-83.

[10] Lou Y, Yousef AE. Adaptation to sublethal environmental stresses protects Listeria monocytogenes against lethal preservation factors. Appl Environ Microbiol 1997; 63: 1252-5.

[11] Giotis ES, Mudcharee J, Wilkinson BJ, Blair IS and McDowell DA. Role of sigB factor in the Alkaline Tolerance Response (AlTR) of Listeria monocytogenes $10403 \mathrm{~S}$ and cross protection to subsequent ethanol and osmotic stress. J Food Prot 2008; 71: 14811485

[12] Giotis ES. The Adaptive Alkali-Tolerance Response in Listeria monocytogenes. Newtonabbey: University of Ulster 2006.

[13] Vasseur C, Rigaud N, Hebraud M, Labadie J. Combined effects of $\mathrm{NaCl}, \mathrm{NaOH}$, and biocides (monolaurin or lauric acid) on inactivation of Listeria monocytogenes and Pseudomonas spp. J Food Prot 2001; 64: 1442-5.

[14] Vasseur C, Baverel L, Hebraud M, Labadie J. Effect of osmotic, alkaline, acid or thermal stresses on the growth and inhibition of Listeria monocytogenes. J Appl Microbiol 1999; 86: 469-76.

[15] Cheroutre-Vialette M, Lebert I, Hebraud M, Labadie JC, Lebert A. Effects of $\mathrm{pH}$ or $\mathrm{a}_{\mathrm{w}}$ stress on growth of Listeria monocytogenes. Int J Food Microbiol 1998; 42: 71-7.

[16] Palumbo MS, Beers SM, Bhaduri S, Palumbo SA. Thermal resistance of Listeria monocytogenes and Salmonella spp in liquid egg white. J Food Prot 1996; 59: 1182-6.

[17] Laird JM, Bartlett FM, McKellar RC. Survival of Listeria monocytogenes in egg washwater. Int J Food Microbiol 1991; 12: 115-22.

[18] Giotis ES, Muthaiyan A, Blair IS, Wilkinson BJ and McDowell DA. Genomic and proteomic analysis of the Alkali-Tolerance Response (AITR) in Listeria monocytogenes 10403S. BMC Microbiol 2008; 8: 102 .

[19] Labbe RG, Reich RR, Duncan CL. Alteration in ultrastructure and germination of Clostridium perfringens Type-A spores following extraction of spore coats. Can J Microbiol 1978; 24: 1526-36.

[20] Duncan CL, Reich RR, Labbe RG. Germination of heat altered and alkali altered spores of Clostridium perfringens type altered by Lysozyme and an initiation protein. J Bacteriol 1972; 109: 550559.

[21] Jacobsohn MK, Lehman MM, Jacobsohn GM. Cell membranes and multilamellar vesicles - influence of $\mathrm{pH}$ on solvent induced damage. Lipids 1992; 27: 694-700.

[22] Mendonca AF, Amoroso TL, Knabel SJ. Destruction of Gram negative foodborne pathogens by high $\mathrm{pH}$ involves disruption of the cytoplasmic membrane. Appl Environ Microbiol 1994; 60: 4009-14. 
[23] Giotis ES, McDowell DA, Blair IS, Wilkinson BJ. Role of branched-chain fatty acids in $\mathrm{pH}$ stress tolerance in Listeria monocytogenes. Appl Environ Microbiol 2007; 73: 997-1001.

[24] Almakhlafi H, Lakamraju M, Podhipleux N, Singla B, McGuire J. Measuring surface hydrophobicity as compared to measuring a hydrophobic effect on adhesion events. J Food Prot 1995; 58: 1034-7.

[25] Malits A, Peters F, Bayer-Giraldi M, et al. Effects of small-scale turbulence on bacteria: a matter of size. Microbial Ecol 2004; 48: 287-99.

[26] Shi BH, Xia XH. Morphological changes of Pseudomonas pseudoalcaligenes in response to temperature selection. Curr Microbiol 2003; 46: 120-3.

[27] Rosenberg M. Bacterial adherence to hydrocarbons - a useful technique for studying cell-surface hydrophobicity. FEMS Microbiol Lett 1984; 22: 289-95.

[28] Rosenberg M, Gutnick D, Rosenberg E. Adherence of bacteria to hydrocarbons - a simple method for measuring cell surface hydrophobicity. FEMS Microbiol Lett 1980; 9: 29-33.
[29] Aldsworth TG, Sharman RL, Dodd CER. Bacterial suicide through stress. Cell Mol Life Sci 1999; 56: 378-83.

[30] Moser I, Schroder W. Hydrophobic characterization of thermophilic Campylobacter species and adhesion to INT 407 cell membranes and fibronectin. Microbial Pathog 1997; 22: 155-64.

[31] Chae MS, Schraft H, Hansen LT, Mackereth R. Effects of physicochemical surface characteristics of Listeria monocytogenes strains on attachment to glass. Food Microbiol 2006; 23: 250-9.

[32] Cuperus PL, van der Mei HC, Reid G, et al. Physicochemical surface characteristics of urogenital and poultry Lactobacilli. J Colloid Interface Sci 1993; 156: 319.

[33] To MS, Favrin S, Romanova N, Griffiths MW. Postadaptational resistance to benzalkonium chloride and subsequent physicochemical modifications of Listeria monocytogenes. Appl Environ Microbiol 2002; 68: 5258-64.

[34] Padan E, Bibi E, Ito M, Krulwich TA. Alkaline pH homeostasis in bacteria: new insights. Biochem Biophys Acta 2005; 1717: 67-88.

Received: December 29, 2008

Revised: May 19, 2009

Accepted: May 19, 2009

(C) Giotis et al.; Licensee Bentham Open.

This is an open access article licensed under the terms of the Creative Commons Attribution Non-Commercial License (http://creativecommons.org/licenses/by-nc/3.0/) which permits unrestricted, non-commercial use, distribution and reproduction in any medium, provided the work is properly cited. 